\title{
Psycho-Dimension of Herdsmen and Their Implication to National Development
}

\author{
John Nwanegbo-Ben \\ Directorate of General Studies, Federal University of Technology, Owerri, Nigeria
}

Email address:

johnjnb5005@gmail.com

\section{To cite this article:}

John Nwanegbo-Ben. Psycho-Dimension of Herdsmen and Their Implication to National Development. International Journal of Philosophy. Vol. 7, No. 1, 2019, pp. 20-23. doi: 10.11648/j.ijp.20190701.13

Received: August 12, 2018; Accepted: January 2, 2019; Published: January 30, 2019

\begin{abstract}
Herdsmen have been parts and parcel of the Nigerian social milieu. Their presence are more in the Northern parts of the country. Recently, there has been deadly clashes between what we now observe as Fulani herdsmen and local farmers. These clashes have gone beyond farm disputes to military raids on communities. These herdsmen have been classified as terrorists by many organizations and groups, however, the federal government of Nigeria has not officially said so. Attempts have been made by the federal government, states and local communities to resolve the insecurity posed by these raids. Despite these attempts, there appears to be some forces militating against this resolution and this has raised suspicion of ethnic cleansing among leaders of thought. The inability of a total resolution has been affecting security and economic development in Nigeria. This paper hopes not only to be analytic and speculative in its method of assessment of the situation, but proposes inter alia a situation of altered states of consciousness and psycho-condition mentality as part of the problem. In addition, the paper shall be prescriptive in nature in order to resolve the assumed force militating against its resolution.
\end{abstract}

Keywords: Herdsmen, Fulani, Altered States of Consciousness, Government, Farmers

\section{Introduction}

It has been a normal phenomenon seeing herdsmen with their cattle on the highways in Nigeria. Herdsmen have been known and seen carrying sticks or sometimes bows and arrows. They were considered harmless and do not pose a threat to people and properties except on rare occasions when their cattle strayed into people's farms by the roadside. Cattle rearing has been an exclusive interest of the northern people of Nigeria, especially the Nomadic Fulanis. Cattle has been one of the major livelihood of the northern communities.

As against the known peaceful herdsmen, current news in print and electronic media has been prevalent with issues that involve violent clashes between farmers and herdsmen. Most times, the news are replete with unprovoked military raids on communities by these herdsmen. Now the once known harmless stick and bow and arrow carrying herdsmen are now carrying sophisticated AK47 rifles which cost more than all the cattle on transit with them. With these development they are no more classified in common parlance as herdsmen, but emphatically "Fulani herdsmen". Tochukwu Ezukanma
[1] observed that there are inherent conflicts between sedentary farmers and itinerant herdsmen because of their competing needs for water and ever diminishing arable land and pastures. These conflicts have led to clashes on farmers by these herdsmen and it has been too frequent an superfluously violent and extremely deadly. . With these clashes, feelers from the stock market shows that investors have lost a whooping \#729 billion to election anxiety in just a few months off decline. [2]

The question now is who are these new breed of Fulani herdsmen? How did they transmogrify into sophisticated weapon carriers? How come they carry weapons whose costs far exceed the whole herd of cattle in their possession? Are these violent clashes sponsored by some unknown high and powerful individuals in authority? Why has none been arrested and prosecuted. What altered the state of conscience of these herdsmen to be heartless in their devastations as against what we thought we perceived of them. In addition, what implication has these imbroglio on the Nigerian economy? These and others shall be assessed in this paper. 


\section{Fulani Herdsmen in Nigeria}

Issues bordering on Fulani herdsmen and farmers is not peculiar to Nigeria. Reasons are that the Fulani tribe is in all of Africa, but most predominant in West Africa. They generally speak the Fula Language. About eighty percent of them are nomadic in nature herding cattle, goats and sheep across dry grass lands.

Omawumi [3] described them as ... the world's largest pastoral nomadic group. It should be noted that grazing lands in the home state of the Fulani's have drastically reduced overtime due to desertification.

Olayoku [4] posits that the Fulanis are the mainstay of cattle herd and milk industry which account for about $90 \%$ of the cattle herd ownership that make $3.2 \%$ of Nigeria GDP.

There is a claim of historical link between the Fulanis and Egypt. They are seen as gypsies, descendants or sons of Roman legionaries that were lost in Sahara. Legends of Islam explained that Arabs in order to convert the local pagans to Islam married their women. A Fulani proverb says that: cattle surpass everything, it's more important than father and mother. If cattle die, then Fulani dies. [5] This proverbs brings to light an incident which occurred in UmuahiaOkigwe road in the eastern part of Nigeria few years back. A lorry load of gravels ran into a herd of cattle that strayed into the high way, one was killed in the accident. The herdsman in charge began to cry uncontrollably he could not be consoled. Sympathizers came and told him that he should be grateful to God that he was not the one that died but just one of his cows. The herdsman replied that it would have been better if he had died because he has no financial value because nobody would buy him. His cow (he concluded) can be bought and that is of great financial value more than himself. This shows the value placed on cattle far above the lives of man by the Fulanis.

Colonization and the fall of Sokoto Caliphate in the $19^{\text {th }}$ century contributed to the dispersal of the Fulanis to the south. The Fulani herdsman with the conquest of Sokoto Caliphate by Great Britain were made to pay "Jangali" (cattle tax). Under the leadership of Uthman Dan Fodio at that time, many poor Fulanis were struggling to make ends meet thus they migrated. The migration of the Fulanis were due to unfavourable climatic condition and governmental encroachment through tax.

Can the migration of the Fulani herdsmen to the southern part of Nigeria be seen as a blessing or curse? In disguise it was a blessing since it eased the suffering of the herdsmen as they grazed into the rich rain forest with great vegetation. Their migration brought cattle to the south that also fertilized the soil during grazing. This however also became the pivot of clashes between two culturally different people.

\subsection{The Psycho-Dimension of the Fulanis and the Nigerian Social Milleu}

The social psyche of Nigerians is divided into the consciousness of believing that the three major tribes Igbo, Yoruba and Hausa/Fulani have peculiar behavioral pattern or characteristics. Bearing in mind that one may be faulted on the grounds of argumentum ad Populum, one may draw from assumed general claimed that the Igbos love money, are shrewd, proud and determined to get what they want. The Yorubas are witty, noisy, crafty but withdraws when fight ensures, while the Hausa/Fulani are seen as docile unmaterialistic but brave and deadly when provoked. These perception may be that of the common man in the streets as it has to do with the three major ethnic nationalities in Nigeria.

The Hausa/Fulanis were seen in common parlance as not materialistic, greedy nor do they pose a threat generally as thieves or robbers. Many in the southern part of Nigeria prefer having them as dedicated security guards who are not inclined to amass wealth or steal people's property. They have been noted as peaceful, harmless but not to be provoked because they would not hesitate to hack or stab you to death. This appears to be in contrast to the claimed peaceful disposition they are perceived to be.

It has been observed that within this assumed docile, peaceful or unmaterialistic nature of the Fulanis is an inner pride of selfesteem as custodians of political power and authority. They have a stoic attitude to life, probably preconditioned by their nomadic lifestyle and religion. Religion may not be a major influence because it did not really change the ethos of people in other tribes that are in the same religion.

The question now is what made the Fulani herdsman Vicious and brutal as against what was perceived of them? Is there the possibility of an altered state of consciousness as against what has been noted of them? Or has personality disorder been activated due to superiorly complex?

\subsection{The Change}

The change from the popular appellation of cattler-rearers and herdsmen to dreaded "Fulani herdsmen" has been a food for thought. It is not the case that they have been known as Fulani herdsmen, but that in recent times within the Nigerian social milieu the words "Fulani herdsmen" connotes terror, bloodbath and violent attacks. The question once again is when did the Fulanis transmogrify into this mode of brutal bloodbath?

We have stated that one of the peculiar characteristics of the Fulanis despite the general perception that they are docile, unmaterialistic but possess an inner pride of selfesteem. Despite the statistics showing that a greater part of the uneducated persons are from the north especially the nomadic Fulanis, there is this pride and mentality of "Born to rule". This "born to rule" was seen in the Sokoto state plate numbers, though Farooq Kperogi [6] argued that this claim was falsehood. This slogan has since been replaced after objections were raised by Nigerians from several works of life. There has however been various arguments to the truth or falsity of this "born to rule" mentality assumed to have been exclusive to the Fulanis.

\section{Altered State and Personality Disorder}

Through history, one could be gradually exposed to how 
easily the human mind could be manipulated by propaganda, indoctrination and brainwashing. "Through speech comes the power to manipulate or persuade people without necessarily resorting to physical force" [7] Due to the nomadic nature of the Fulanis, they hardly receive western education. The adoption of Islam increased the Fulanis feeling of cultural and religious superiority to surrounding people; it became a major boundary mark.

Propaganda and indoctrination can turn a gentle-man to a beast, any wonder Karl Marx posited that "religion is the opium of the masses? Religion and culture of the Fulanis appears to have beclouded the judgment of mostly the uneducated nomadic Fulanis. There appears to be a false sense of reality among the modern day nomadic Fulani. This reality we may postulate was motivated and preconditioned by fanatic religious leaders that are in search of political power.

It would be pertinent to note that ignorance and poverty are major forces upon which men can be manipulated. Men's state of consciousness can be altered when ignorance and poverty are displayed. Can you imagine a situation where a man is told that a large sum of money would be paid to his family if he would volunteer to die as a suicide bomber? And that dyeing as a suicide bomber would earn him a position in heaven. Ignorance and poverty is the only key that can make a man to be conditioned and lose natural reasoning that gives way to beastly acts.

The National chairmen of Fulbe (Fulani) Development Association of Nigeria (FULDAN) Malam Ahmed Usman Bello declared that Fulani cannot be beaten by any ethnic group in Nigeria. He posits openly that "any ethnic group that fights it would be doing so at its own peril" [8]. This statement is a clear indication of one who appear to have superiority complex. It is a statement that can motivate and instigate fears among minority nationalities and draw up a sense of superiorly in the minds of the Fulanis especially the poor ignorant ones. These class of the ignorant ones will see it as a point of personal feeling of superiorly despite the social situation they have found themselves. This consciousness can invoke a warrior instinct and sense of being destructive. Due to lack of positive response to this outrage by the Fulani, leaders of thought have conjectured that there must be a hidden agenda for an ethnic cleansing by the ruling government of Mohamed Buhari.

\subsection{The Psycho-Dimension Paradox}

We definitely live in a world that urges us to compete with others hoping to get the level we want in life. The problem is when the battle is within. One rages on between yourselfconcept and the true identity of the person. The result is wearing a mask that is not true. The paradox is that superiorly complex is as a result of deep seated and repressed feeling of inferiority complex or lack of self-esteem. One may not be surprised at a sudden transmogrification of the stick carrying Fulani herdsman to AK47 rifle carrying herdsman. The reason could be that they have been generally classed as uneducated, poor, nomadic, docile and unmaterialistic in nature. We have also seen the general perception about them that they should not be provoked less they hack you down with their knives which they carry freely. This behavior exemplifies a repressed feeling of complex of the poor and inferior personality. The superiorly complex is a personality disorder and altered state of consciousness. This makes men do and act beyond their normal life. They tend to over exaggerate in order to feel more important, this is the case of Ahmed Usman Bello, the chairman of Fulani Development Association of Nigeria. The Association tend to prove the hypothesis we have tried to postulate. It is an association meant to develop them from their state of poverty, uneducated level to meet with contemporary standard of development. When the superiority ideology is proffered to the illiterate and uneducated Fulani and backed by a false religious doctrine, it becomes a means of exposing their repressed feeling, thus the violence and bloodbath and transmogrification from stick carrying to AK47.

With attacks and multiple killings and destruction of lives and properties in Benue state, Kaduna, Taraba and most northern states, groups and NGOs have advocated to declare them as terrorist group, yet the federal government kept silent about it.

\subsection{Fulanis and the Nigerian Economy}

Fulani herdsmen and farmers crises has affected almost all fabric of the Nigerian economy. With the new onslaught going on, whether deliberately propelled or naturally induced by human frailty, the problem is that it has affected the Nigerian economy. Normal "cattle rearers" are now afraid not to be classified as Fulanis in order not to be harassed by aggrieved natives who have witnessed bloodbath by the raids of Fulani herdsmen. Secondly, outcry to avoid cattle by most southerners in order to stop Fulani incursion has reduced the purchase of cows for festivities. Trade in cattle has been affected, yet the federal government of Nigeria is not addressing the economic consequences of the conflict

A committee was set up by the vice president to look into the issue Dele Sobowale [9] described that members of the committee were reluctantly appointed by Buhari. The constitution of the committee was described as a "diversionary, unconstitutional and irrelevant".

In the process of this conflict there is food insecurity as crops are destroyed and planting deferred due to fear from attacks. Farms are abandoned and even harvested crops are left to rot away. The 1996 world food summit states that food security "exist when all people, at all times, have physical and economic access to sufficient, safe and nutritious food to meet their dietary needs and food preferences for active and healthy life" [10] Apart from loss of lives, farmlands, food produce and property, there is polarization of communities as a result of herdsmen activities. For fear of attacks, farmers do not go to farms any longer.

The president, a Fulani is distrusted by those affected by the crises. He is perceived as an advocate of the herdsmen, reasons are that solutions required to wipe out further 
economic loses occasioned by the herdsmen is not coming from him. Thousands of people have died as villages are raised down by herdsmen. Sometimes intelligent security reports are sent to inform security operatives of impending attacks, but almost all the time no response to such information even took place.

The activities of the Fulani herdsmen has brought sorrow, pain and tears to families in Nigeria. A major paradox within this imbroglio is the perception that it is a religious war, a Jihad and a form of ethnic cleansing by the fulanis. The concept that is a Jihad have brought division in the minds of Nigerians. Liberal Muslims don't know if to accept it as a major precept of Islam or to be cautions since it is being fully executed exclusively by the fulanis. Reason is that some Muslim communities have also been raided and mosques also destroyed.

Attacks has been more within the Christian communities as churches are destroyed and Christians killed. When schools are raided and students kidnapped, the Muslims students are released while the Christian would be asked to renounce their faith in favour of Islam before being released. A major issue is the Dapchi school girls kidnapped by the Boko Haram were they refused to release a Christian alongside her 104 kidnapped colleagues for not renouncing her Christianity.

The government has been blamed for insensitivity on this, thus a group that called themselves the Afenifere asked the United Nation to investigate the situation in Nigeria. They must investigate the genocide and bring the appropriate international sanctions against the Nigerian government for promoting, aiding and abetting genocidal conduct by armed Fulani herdsmen across the country". [11]. The observation by many who have been directly and indirectly affected, the Boko Haram and the herdsmen are all fulanis. This appears why up till date the government have not been able to find solutions to the problem. It is assumed that the government has special interest on what is going on due to the fact that the fulanis are involved.

\section{Recommendation}

The only way to totally return Nigeria to its enviable height is, first of all, the government should start identifying and arresting culprits of this dastardly acts. They must not be allowed to go free. The mayhem is continuing because the government has not seen it imperative to arrest any of them. Those arrested are most times released without trials.

Open grazing should be outlawed to prevent herdsmen from destroying farms and farmers properties. The illiterate herdsmen should be educated that restriction of their activities is good for the society.

No herdsman should be allowed to carry fire arms indiscriminately. How can a herdsman carry a sophisticated AK47 that cost more than his herd of cattle? The issue is that they were provided by the rich cattle owners in government and that is why they cannot be arrested or prosecuted. All those found with firearms should not only be disarmed but arrested with the owners of the cattle. Rich husbandmen should invest in ranches by buying large portions of lands. Animal husbandry is a private business like others thus they should invest properly and restrict their cattle to their ranches.

\section{Conclusion}

The problem of herdsmen and farmers in Nigeria is not just a social menace that has been eating deep into the economy of Nigeria, but has a deep seated psychodimension. To really resolve this anomaly, we need the education and enlightenment of the uneducated and uninformed being utilized by wealthy cattle owners and religious intolerant psychopaths. By implication poverty and ignorance has been a motivating force that makes men take pea nuts or promises of rewards in heaven to kill their fellow men. The resolution to this problem should really begin by the psycho-conditioning of all whose consciousness have been altered towards bloodbath.

\section{References}

[1] Tochukwu Ezukanma (2018) Ominous silence of Fulani herdsmen. https://guardian.ng/tag/fulani-herdsmen. Retrieved 28/12/2018

[2] The 2019 election and the economy. https://guardian.ng/opinion/the2019-election-and-the-economy. Retrieved 28/12/2018.

[3] Omawumi, Eyekpim (2016) History of Fulani herdsmen and farmers clashes in Nigeria. https://infoguidenigeria.com/fulaniherdsmen-farmers-clashes. Retrieved 25/3/2018.

[4] Olayoku, P. (2014). Trends and patterns of the cattle grazing and rural violence in Nigeria (2006 - 2014). Nigeria: IFRANigeria walking papers series. No.3.

[5] Soriola, E (2018). History of Fulani herdsmen and farmers clashes in Nigeria and today crises. http//www.naija.ng retrieved 20/3/2018.

[6] Farooq K. Perogi (2015). The stubborn, undying "Born to rule" falsehood in Nigeria's Political discourse. Daily trust 1/1/2013.

[7] Brown. J. A. C (1981). Techniques of persuasion: From Propaganda to Brain Washing Penguin Books Ltd. Middlesex Bryland 1981

[8] Kola Oyeleye (2018). No one can defeat Fulani in Nigeria-Bello, Fulani national leader. 27 Jan, 2018.

www.tribuneonlineng.com/no-one-can defeat - fulani-Nigeriabello-fulani-leader/retrieved 4/21/2018.

[9] Dele-Sobowale (2018). Vanguardngr.com economic consequences-herdsman-farmers-clashes. 3/May/2018.

[10] World food surmit 13-17 November 1996. Rome, Italy. www.fao.org/wfs/.

[11] Temitope Olanipekum (2018). Dapchi school girls: Kidnap release curious -Afenifere dailypost.ng/2018/3/27 dapchischoolgirls-kidnap-release-curious Afenifere. 